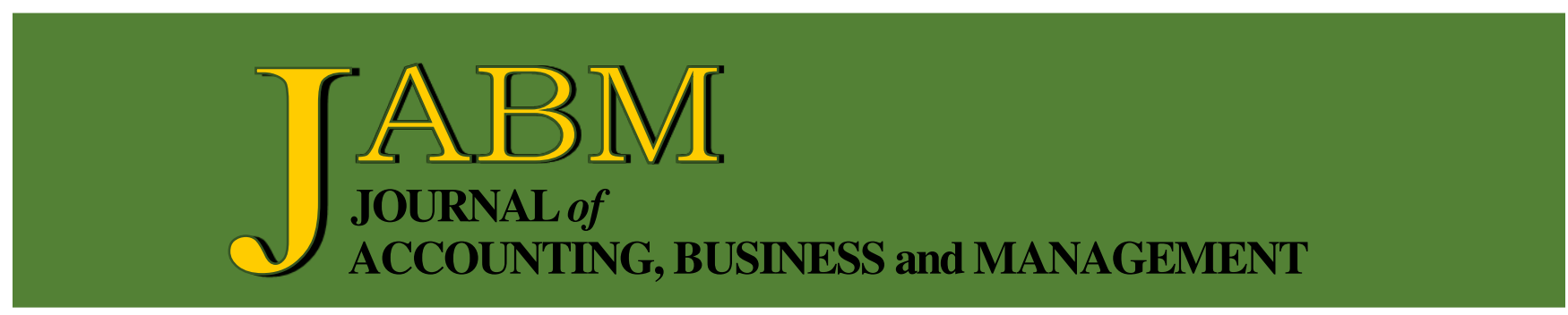

Life Insurance Companies: Determinants of Cost Efficiency and Profitability

Joseph Kwadwo Tuffour, Kenneth Ofori-Boateng, Williams Ohemeng, and Jane Kabukuor Akuaku

Subprime Crisis - A Corporate Acquisition Opportunity?

Vishal Srivastava, Sunder Ram Korivi, and Dipasha Sharma

Consequences of Weak Internal Controls Over Financial Reporting: Foreign versus U.S. Firms

Kathleen Bakarich and Devon Baranek

Impact of Organizational Commitment on Accounting Professionals' Performance: Case of Accounting Firms

Lassaad Abdelmoula and Sami Boudabbous

The Objectives of Sharia Management Accounting Information Reporting: Identification of Values and Characteristics

Sonhaji, Abdul Kadir Usri, and Hedher Tuakia

The Impact of Customer's Perception of the Practices of Corporate Social Responsibility on Purchase Intention

Doaa Abd El Samea and Ahmed Rashed

Corporate Financial Distress: The Impact of Profitability, Liquidity, Asset Productivity, Activity and Solvency

Karikari Amoa-Gyarteng

Determinant Factors of Social Cohesion and Inclusion of Street Vendors in Jakarta: Key Factor Surviving During Covid-19 Pandemic

Beti Nurbaiti 
Journal of Accounting, Business and Management (JABM) vol. 28 no. 2 (2021) 83-103

\title{
The Impact of Customer's Perception of the Practices of Corporate Social Responsibility on Purchase Intention
}

\author{
Doaa Abd El Samea* \\ Ahmed Rashed ${ }^{\dagger}$
}

\begin{abstract}
The scarcity of research on the customer's perception towards corporate social responsibility (CSR) in developing countries has inspired this research. This study aims to measure the impact of the customer's perception of the practice of corporate social responsibility on the purchase intention in the presence of the service quality as a mediator variable. To achieve the aims of this study, the researcher relied on the mixed design of the search. The relevant CSR literature was recapitulated into a conceptual framework and an empirical study that were conducted through a mixed research design. This study reached many of the results, including that there is a direct impact of corporate social responsibility on the purchase intention. Also, there is an indirect impact of the moderating variable of the study, which is service quality of the direct positive impact of both the economic dimension, ethics and philanthropic on purchase intention.
\end{abstract}

Keywords: corporate social responsibility, service quality, purchase intention.

\section{INTRODUCTION}

A corporate social responsibility has become increasingly prominent and an important topic which began to present strongly in recent times, it has also become a vital issue in the developing countries so that it received the attention of many researchers and become a fertile material to a lot of searches after giving up many governments for a lot of its roles towards the community, As a result of economic circumstances that occur and the lack of financial resources in some countries, the numerous researchers made several attempts to study the nature of corporate social responsibility and its importance and also the role they play in society (Carroll, 1979; Arikan \& Güner, 2013; Foo \& Yazdanifard, 2014; and Huang et al., 2014) .

Corporate social responsibility is that in which companies bear economic, legal, ethical, social and philanthropic responsibilities towards stakeholders, and can also be considered a marketing tool that cooperates in the search for differential positioning when managed and communicated well to stimulate consumer reactions (Lacey et al., 2015).

The amount of knowledge about corporate social responsibility has also grown significantly over the past few decades. However, gaps remain in the literature related to corporate social responsibility and its role in furthering the company's strategy (Abdullah \& Budiman, 2019), which caused the disparity in social responsibility definitions for companies and their perceptions. The researchers and managers used different terminology to describe the practices of companies, for example: terminology

\footnotetext{
* Business Administration Department, Faculty of Commerce, Cairo University, Egypt. E-mail: doaa_w1111@yahoo.com.

† Business Administration Department, Faculty of Commerce, Cairo University, Egypt. E-mail: ahmed_rashed@foc.cu.edu.eg.
} 
of social performance of companies, and social response to companies (Kotler \& Lee, 2005), corporate philanthropy (Foster et al., 2009), corporate citizenship (Dentchev, 2009), and corporate sustainability (Garriga \& Melé, 2004), and the business ethics (Dentchev, 2009) with the presence of many different perceptions of the social responsibility of the companies, which have existed since 1950.

Through many previous studies, it became clear that research on corporate social responsibility in developed countries is much more than in developing countries. Although developing countries need much more corporate social responsibility than developed countries, in other words, institutions that provide social goods are generally less in developing countries than in their more advanced counterparts. Under these circumstances, companies tend to yield to high requirements and expectations to fill these gaps (Baughn et al., 2007).

As for the situation in Egypt, the issue of corporate social responsibility still lacks a lot of attention, and based on the foregoing, the researcher will be exposed to clarify the companies' concept of social responsibility and the extent of the development of this concept over the past years, as well as models and theories related to this concept, and will focus on the link between "the perception of clients of this concept and the effect on the intentions of their purchase, where the intention of purchase is the focus of this study; which represents the dependent variable, and the researcher relied on it because it is considered a very important concept in the field of marketing, where when ethical behavior exceeds the expectations of customers it will lead to a positive relationship with the intention of purchase. Applied on mobile communications companies in Egypt."

\section{LITERATURE REVIEW}

\subsection{Corporate Social Responsibility Theories}

The focus was on presenting corporate social responsibility (CSR) to identify the roots and origins of CSR. Most of the current theories of CSR focus on four key aspects:

1) The desired objectives that produce long-term profits.

2) The use of corporate power in a responsible manner .

3) Integrating social demands .

4) Contribute to the existence of a good society by doing what is morally correct.

This allows us to classify the most important theories of corporate social responsibility and related concepts into four groups as a starting point for a correct classification (Parsons, 1961). The source of these hypotheses is four observable aspects: adapting to the environment (resource and economy), attaining the goal (policy), social integration, and finally preserving the pattern (related to culture and values).

\subsubsection{Theories classifications}

\subsubsection{Instrumental theories}

Which assumes that the institution is a tool for wealth creation, and that only the economic side represents the interactions between companies and society, accepting any social activity that is supposed to be compatible with wealth creation, where CSR is understood as a means of profit.

Three main sets of this theory can be identified based on the proposed economic objective: 


\section{a). The first group: maximizing the shareholder value}

The aim of maximizing the value of shareholders' equity, measured in the price of the stock in many cases and this leads in the short term to the direction of profits an agency theory is the most commonly theory of expression of this group (Jensen \& Meckling, 1976).

\section{b). The second group: competitive advantages}

This group focuses on theories about how to allocate resources in order to achieve long-term social goals and create a competitive advantage (Husted \& Allen, 2000).

\section{c). The third group: cause-related marketing}

The objective of this group is to promote corporate earnings and sales, next to enhance customer relationships through brand building next to cooperate with the moral dimension (Murray \& Montanari, 1986; Varadarajan \& Menon, 1988). It seeks to product differentiation by creating attributes of social responsibility that affect the company's reputation (Smith \& Higgins, 2000).

\subsubsection{Political theories}

The social authority of the company is certain, especially in its relationship with society and its responsibilities in the political arena associated with this authority, and this leads companies to accept social duties and rights or participate in certain social activities. There are two main theories that can be distinguished: corporate constitutionality (Davis, 1960), and corporate citizenship (Andriof \& McIntosh, 2001; Matten \& Crane, 2005).

\subsubsection{Integrative theories}

The company must integrate social demands, and usually argue that companies depend on society for their sustainability and growth or even in the presence of the company itself. These theories are subdivided into:

\section{a). Issues management}

This approach examines the gap between what the organization's stakeholders expect and their performance to ultimately achieve the actual performance of the organization. This gap is usually called the "zone if discretion" (Ackerman, 1973). Companies must recognize this gap and choose the appropriate response in order to close them.

\section{b). The principle of public responsibility}

This approach was suggested by (Preston \& Post, 1981) as the "principle of public responsibility" to emphasize the importance of the general process rather than the personal-moral view.

\section{c). Stakeholder management}

The trend in this approach is "stakeholders" or people who influence or are affected by corporate policies and practices (Sturdivant, 1979).

\section{d). Corporate social performance}

It deals with the definition of social responsibility, a full range of obligations due to the companies towards society, and has to embody the economic, legal, ethical , and charitable groups to perform work and then gave it all and classification through "social pyramid Alsiolah companies (Carroll, 1991).

\subsubsection{Ethical theories}

It recognizes that the relationship between business and society is an inseparable part of ethical values, and this leads to a view of corporate social responsibility from an ethical perspective. As a result, companies must accept CSR as a moral obligation above all else (Carroll \& Buchholtz, 2002). This theory contains some approaches, namely: 


\section{a). Universal right}

Human rights have been taken as a basis for CSR, especially in the global market (Cassel, 2001).

\section{b). Sustainable development}

Sustainability is the ideal for society and companies that can constantly strive to create added value and create results that are consistent with the ideals of sustainability along the environmental, economic, and social dimensions.

\section{c). The common good approach}

This approach asserts that business has a contribution to the society in various ways, like: maximize a wealth, efficient provision of services, and it contributes to social well-being to live in fair and peaceful conditions both now and in the future (Garriga \& Melé, 2004).

The following figure will present a summary of these theories, and each group will be presented separately:

\section{Figure 1}

The Conceptual Framework (Developed by the Researchers): CSR (Corporate Social Responsibility) Theories

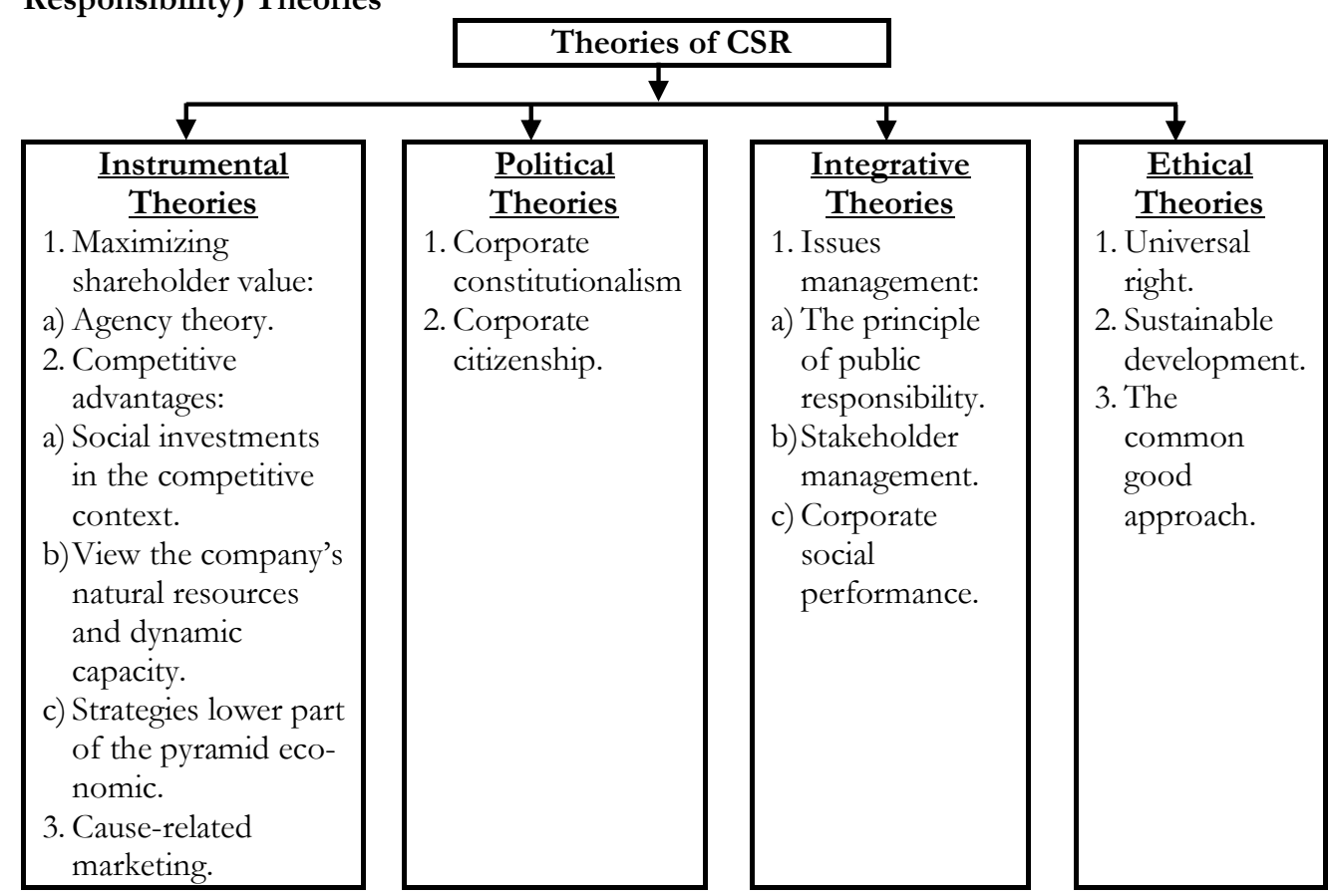

\subsection{Importance of Corporate Social Responsibility}

A lot of researchers and managers think that companies have key responsibilities to the communities where it is present and therefore, should these companies recognize the environmental and social aspects in their companies, which in return reflects the concept of CSR, which captured the attention of both academics and practitioners for several years, including (Foo \& Yazdanifardm, 2014; Huang et al., 2014) comes one of the first studies (Carroll, 1979; Wood, 1991), where it increased adoption of responsibility activities of social enterprises quickly a priority for these companies (Vlachos et al., 2009), as (Chandler, 2019) says, "CSR is not an option; that's what companies do." Now, corporate social responsibility must be seen as part of value 
creation processes. See it as an integral part of the strategic decision-making process to create value.

At the academic level, corporate social responsibility has become more interested in recent years. Whereas, the implementation of social, economic and legal responsibility had a direct and positive impact on the company's reputation, and also boosted the economic performance of consumer confidence (Park et al., 2014). Thus by adopting corporate social responsibility practices, the company not only promotes doing the right thing well, but also does it better, to have a positive impact on the main stakeholders (Martínez et al., 2016).

After referring to the importance of corporate social responsibility through other previous studies that have examined the association between them and the many variables, for example, but not limited (a company's reputation, brand image and loyalty and so on) and its impact on them, whether positively or negatively, comes important to highlight studies, related customers realize the practices of corporate social responsibility as follows:

\subsubsection{Customer's perception to the practices of corporate social responsibility}

There is a group of researchers who pointed out that consumers lack information about the practices of companies in general, such as ethical practices and other company practices. Where there is found to Customer's perception for CSR activities is low for companies in general (Sen et al., 2006) but with interest in the program developed and methods of comprehensive continue to be on the way to raise the level of awareness and understanding of customers (González-Rodríguez \& DíazFernández, 2020)

There are many studies that have agreed on the importance of CSR correlation of companies positively with increased customer's perception, and concluded that for companies with low customer's perception, the relationship is negative or insignificant and vice versa, and this consistent with the opinion that perceiving CSR can Adds value to the company (Servaes \& Tamayo, 2013; Menichini \& Rosati, 2014).

Also (Kolkailah et al., 2012) agree that there is a customer's perception of the concept of corporate social responsibility and that companies tend to develop customers trends and create a positive attitude towards socially responsible companies but they differ with regard to the important point is that when it comes to purchasing, the criteria hosted by customers are evaluated and found Economic standards still take precedence over social norms.

\subsection{Dimensions of Corporate Social Responsibility and Its Impact on Purchase Intention's Customers}

This study discusses the dimensions of corporate social responsibility following the model of (Carroll, 1979) hierarchical and represented in the "economic, legal, ethical, and philanthropic responsibility" as the model deals with the dimensions of corporate social responsibility hierarchically in order of decreasing importance as this model of economic responsibility and are the most the importance of which is the base upon which the rest of social responsibilities:

\subsubsection{Economic responsibility}

Some consumers believe that economic responsibility is not part of a company's social responsibility, its primary presence and a primary goal for the organization (Gopal \& Srinivasan, 2006). While (Carroll, 1979; Henderson, 2007) pointed out in business, economics is the main driver of society, where making profits creates social responsibility. 
But as a prerequisite for existence, companies have an economic responsibility to society for sustainability. At first, it may seem uncommon to think of economic expectations as a social responsibility, but society expects business organizations to be able to support themselves and then help society and the only way to do this is to be profitable and able to motivate owners or shareholders to invest and have sufficient resources to continue working (Carroll, 2016).

\subsubsection{Legal Responsibility}

Community not only punished corporations, but also set the minimum basic rules on which corporations are expected to operate and operate. These basic rules include laws and regulations and actually reflect the viewpoint of society about "codified ethics" (Carroll, 2016). As explained by (Argo \& Main, 2004; Torres et al., 2007) that the companies have a legal obligation to provide consumers with information about products, which has the intention to purchase, based on the practices of corporate social responsibility, the responsible companies socially keen to reassure consumers by enhancing the decade social between companies and consumers (Torres et al., 2007; Wang, 2009).

\subsubsection{Ethical Responsibility}

Companies must fully commitment with ethical responsibility towards shareholders, and society, to undertake ethical and correct work for all stakeholders (Abdullah \& Budiman, 2019). Where consumer responses are mainly affected by the consumer's awareness of ethical responsibility, belief in them and the ability of companies to apply this responsibility and develop a general framework for the consumer's ethical response as well as how to stimulate suggestions that provide consumer support towards the ethical behavior of the company and then turn this support into a positive buying behavior (Deng \& Qian, 2011). Where there is the influence of the ethical responsibility practiced by the organization when making a purchase customers decision to always expect the commitment of organizations morality in their actions (Ling et al., 2010).

Some researchers argue that there is disagreement on the impact of ethical responsibility on the intention of buying customers (Valand et al., 2008) and some of them believe that ethics is an integral part of the conscience and the characteristics of the human part, the part of the profile of the launch of any human work (Potočan \& Mulej, 2009). He held (Walker \& Brammer, 2009) survey of a sample of consumers and the results of the survey indicated that the company that owns an ethical acts be better able to attract clients either not be buying their products with equal in quality, price and service quality the other of them have purchase incentive more regardless of price.

\subsubsection{Philanthropic Responsibility}

The Philanthropic dimension differs from other dimensions of corporate social responsibility because it has a voluntary CSR appearance, but the social, legal, or moral/corporate social responsibility dimensions involve societal obligations imposed on the company (Hsu, 2012). Some studies have found that when organizations responsible charities adopt as part of its social responsibilities, this will reflect positively on the choice of consumers for products of these organizations decisions (Lichtenstein et al., 2004) are working to create a positive image of the organization and thus lead to the availability of buying intentions positive for their products (Cornwell \& Coote, 2005). 
Figure 2

Carroll (1991) Corporate Social Responsibility Pyramid

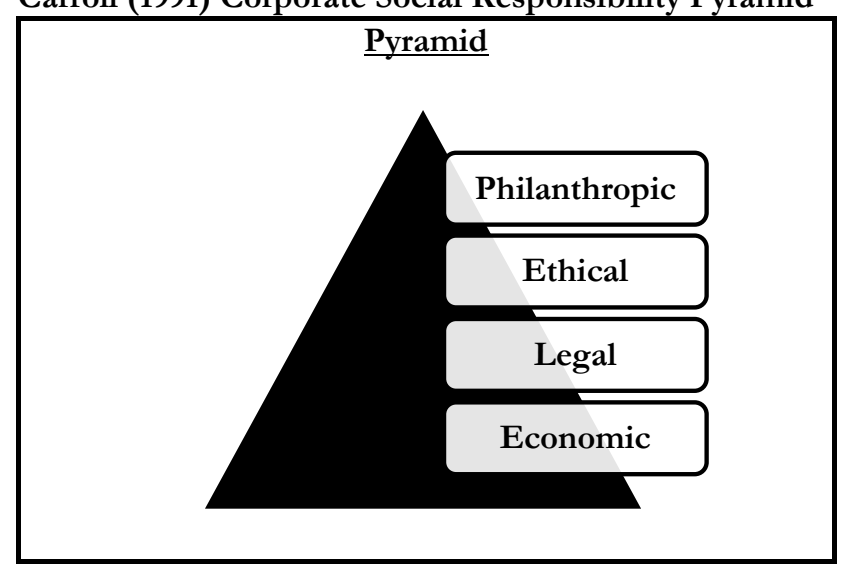

2.4. Relationship between CSR and Service Quality

Service quality is widely recognized as the main influence on the relationship between the customer and the company relationship ( $\mathrm{He} \& \mathrm{Li}, 2011)$. He also experimentally found that corporate social responsibility is a strong indicator of the overall service quality of a company. It has been widely discussed as a source of positive attitudes among clients (Walsh \& Bartikowski, 2013; Fatma et al., 2016). Some of studies considered that social responsibility must be understood as ethical behavior of the company and yet another element of service quality (Sureshchandar et al., 2002) where their assessment of the quality of service on this basis begins and therefore can be considered that there may be a direct relationship between consumer's perceptions when assessing service provided by the company, It should promote social responsibility on an equal par with quality and make them an essential component to ensure a sustainable future for all (Staiculescu, 2014; Wattanakamolchai et al., 2014).

\subsection{The Relationship between CSR and Purchase Intention}

Numerous researchers have found evidence of the impact of corporate social responsibility on the intention to purchase (Gigauri, 2012). Other research using the focus group discussion also found that corporate social responsibility in the company will in one way or another affect the intention of the client's purchase, bearing in mind that it should be noted that the customer will not request such information instead he will wait to be informed (Abdullah \& Budiman, 2019). Others also expounded that the impact of CSR on the buying intentions of consumers is more complicated than he thought where can CSR affect firms directly affect or indirectly, to the purchase intentions, where direct effect is when reflect the activities of corporate social responsibility and consumer or beliefs depending on the degree of consumer confidence that corporate social responsibility and institutional capacity as well as consumer support for the behavior of the social responsibility of companies. Also there is a small segment of the consumers are using the practices of corporate social responsibility and consider them as a criterion for purchase (Mohr \& Webb, 2005; Foo \& Yazdanifard, 2014; and Xu, 2014).

\subsection{The Relationship between Service Quality and Purchase Intention}

Some studies have confirmed that there is a positive association between customers perceptions of service quality and their willingness to recommend for a company where the customer to recommend the company for other customers and 
mentions are positive things about the company and encourage friends and relatives to do to deal with the company (Parasuraman et al., 1993; Zeithaml et al., 1996).

Service quality has many dimensions, each dimension has a different effect on Purchase intentions of customers where there is found that reliability is the tangibility of the most powerful influence on purchase intention of customers and others have concluded that the reliability and tangibility and response are the same coherent and strong impact on customer purchase intentions, Also effect of the dimensions is not equal to the customer where they are between satisfied and not satisfied (Huang et al., 2011; Vaijayanthi et al., 2012; and Choudhury, 2013). While there are those who believed that five dimensions of service quality have influence on purchase intent (Pérez et al., 2007).

\section{RESEARCH METHODOLOGY}

In order to achieve the objectives of the study, the researchers adopted the mixed design research, which consists of two phases: Phase 1 was an exploratory study focusing on the descriptive methods to determine the problem of study and formulation of hypotheses. Malhotra and Birks (2007), while phase 2 entailed a descriptive research to test the hypotheses of the study by collecting data and information and analyzing it structurally in a digital format that allows the distribution of the results in a statistically significant manner in relation to the causes and solutions of the problem under study. This approach achieves the research objectives and helps to test hypotheses and to draw conclusions and interpret them.

\section{Phase 1: exploratory study}

During this phase, the researchers worked on several methods to ascertain the validity of the content of the survey list, which will be directed to the sample later. These methods include: review of previous studies - interviews with clients - in-depth interview - expert review.

\section{Phase 2: descriptive research}

Is the next stage of exploratory research where it is the scientific framework for research design for decision-making in determining and selecting the best means to reach the best results (Malhotra, 2011).

\section{Sampling process and data collection}

The researchers have chosen a systematic probability sample, which is characterized by increasing the representation of the study community and impartiality, through the customers of Vodafone, Mobinil, and Etisalat as companies participating in the practices of corporate social responsibility, where in this type of samples get a list or number (such as, all customers who come daily to branches). The telecommunications sector was chosen as a sample of the research paper, as it is one of the most important sectors of the application of CSR, and it represents a large percentage of the study society as described in the research. The systematic sample is obtained by dividing the size of the sample according to the size of the community. According to the size of the community is greater than a million client, so the researchers will be snapped 384 of the vocabulary of a single research community, and that significant level $\pm 5 \%$, and $95 \%$ confidence level (Krejcie \& Morgan, 1970; Collis \& Hussey, 2009).

\subsection{Models and Hypotheses of the Study}

\section{1). Hypotheses of the study}

Through the objectives of this study and the previous studies which have been mentioned previously (Rexhepi et al., 2013; Park et al., 2014), and also the impact CSR 
on purchase intention and service quality (Gopal \& Srinivasan, 2006; Lee et al., 2009; Wang, 2009; Deng \& Qian., 2011; and Hassan et al., 2014).

Through this being formulating hypotheses of the study as follows:

Many studies have reached for a direct effect to customer's perception to the dimensions of the practices of corporate social responsibility on the purchase intentions (Mohr \& Webb, 2005; Sen et al., 2006; Foo \& Yazdanifard, 2014; and Xu, 2014), Also having a direct significant effect between every dimension of corporate social responsibility, which represented in (economic, legal, moral, and philanthropic dimension) on purchase intention (Lantos, 2001; Cornwell \& Coote, 2005; Gopal \& Srinivasan, 2006; Henderson, 2007; Wang, 2009; Ling et al., 2010; and Deng \& Qian, 2011).

And can then be research hypotheses, which constitute of the proposed model to search through critical review for previous studies, as in the following figure model:

Figure 3

The Conceptual Framework

Independent Variable

Dependent Variable

\begin{tabular}{|l|l|}
\hline - Costumer's Perception of CSR: \\
- Economic dimension \\
- Legal dimension \\
- Ethical dimension \\
- Philanthropic dimension
\end{tabular}

In the light of these previous studies being the formulation of the following hypotheses:

Ha: there is a positive impact on economic dimension on purchase intention (Carroll, 1979; Maignan \& Ferrell, 2003; Gopal \& Srinivasan, 2006; and Henderson, 2007).

$\mathbf{H a}_{2}$ : there is a positive impact of on the legal dimension on purchase intention (Argo \& Main, 2004; Torres et al., 2007).

$\mathrm{Ha}_{3}$ : there is a positive impact on ethical dimension on purchase intention (Potočan \& Mulej, 2009; Ling et al., 2010; and Deng \& Qian, 2011).

$\mathrm{Ha}_{4}$ : there is a positive impact on - Philanthropic dimension on purchase intention

(Payton, 1988; Lichtenstein et al., 2004; and Cornwell \& Coote, 2005).

Also, many studies have proved a positive effect between corporate social responsibility and service quality (Chen et al., 2012; Arikan \& Güner, 2013; and Wattanakamolchai et al., 2014) Therefore, this study examines the existence of significant positive effect directly between the dimensions of corporate social responsibility and quality of service, and through the formulation of the following hypotheses:

$\mathbf{H b}_{1}$ : there is a positive effect for the economic dimension on service quality.

$\mathbf{H b}_{2}$ : there is a positive effect for the legal dimension on service quality.

$\mathbf{H}_{\mathrm{b} 3}$ : there is a positive effect for the Ethical dimension on service quality

$\mathbf{H}_{\mathrm{b} 4}$ : there is a positive effect for the philanthropic dimension on service quality.

The following studies discussed (Zeithaml et al., 1996; Kuo et al., 2009; Gottlieb et al., 2011; Huang et al., 2011; Vaijayanthi et al., 2012; and Choudhury, 2013), there is a 
positive effect between the practices of corporate social responsibility and purchase intention, and through these studies will be the formulation of hypothesis next:

$\mathbf{H}_{\mathbf{c}}$ : there is positive effect on the service quality between purchase intentions.

Other studies on the impact of practices of corporate social responsibility on purchase intention in the presence of a service quality as a mediator variable and this is a brief summary of each study (Welford, 2004; Haung et al., 2014)

$\mathbf{H}_{\mathrm{d}}$ : there is positive effect indirectly between the dimensions of corporate social responsibility on the purchase intention through service.

\section{EMPIRICAL RESULTS}

\subsection{Descriptive Analysis}

This section describes the characteristics of the respondents. Before conducting the confirmatory factor analysis (CFA). The researcher runs the exploratory factor analysis (EFA) in order to assign each item of service quality on a dimension of service quality dimensions. Also, the researcher used structural equation modelling (SEM using smart PLS v.3.3 (Ringle et al., 2015). So, the most alternative software to treat with non-normal data is smart PLS (Hair et al., 2012).

\subsubsection{Profile of respondents}

Table 1

Sample Description

\begin{tabular}{lcc}
\hline \multicolumn{1}{c}{ Sample Description } & Frequency & Percentage (\%) \\
\hline 1. Telecommunication company: & & \\
- Vodafone & 128 & 33.3 \\
- Etisalat & 128 & 33.3 \\
- Mobinil & 128 & 33.3 \\
2. Age: & & \\
- Less than 30 years & 123 & 32 \\
- From 30 to less than 39 years & 122 & 31.8 \\
- From 40 to less than 49 years & 90 & 23.4 \\
- 50 years and more & 49 & 12.8 \\
3. Education level: & & \\
- Secondary school & 43 & 11.2 \\
- High education & 229 & 59.6 \\
- Masters or MBA & 15 & 3.9 \\
- PhD & 11 & 2.9 \\
- Others & 68 & 22.4 \\
4. Gender: & & \\
- Female & 174 & 45.3 \\
- Male & 210 & 54.7 \\
\hline
\end{tabular}

\subsection{Validity, Reliability of Scales and Testing of the Hypotheses}

A systematic approach was taken to validate the proposed model (Henseler et al., 2009; Hair et al., 2014). Convergent validity was assessed by examining the minimum requirements for factor loadings and the average variance extracted (AVE) of the constructs. In examining the AVE, it was found that the AVE of all constructs were less than 0.5 (the recommended threshold) except philanthropic and purchase intentions. Therefore, items economic 1, 2 and 5, legal 2 and 3, ethics 4, tangibility 1,2, 3,5 and 6 , reliability 1,2,3 and 4, responsive 3 and 6 , empathy 1, 3, 4, 5 and 6 and assurance dimension were eliminated since they had the lowest loading on their constructs in order to generate the measurement model. 
The factor loadings were higher than 0.708 even if there are some indicators that less than this cut-off point, the other indicators that have the high loading substitutes the decrease in these indicators. All of the AVE were higher than 0.50 (Hair et al., 2014). According to discriminant validity, all constructs met the $\mathrm{HTMT}_{0.85}$ criterion (the conservative criterion). Moreover, all constructs satisfied the recommended cut-off point for establishing composite reliability (CR) which is higher than 0.70 (Hair et al., 2014), where the CR constructs ranged between 0.80 and 0.95 . Consequently, the $\mathrm{R}^{2}$ for service quality and purchase intensions were very acceptable. Next a bootstrapping procedure, with 5000 subsamples, was applied to obtain inference statistics, as illustrated in Table 2.

Table 2

Measurement Model Evaluation and the Findings about Direct Paths

\begin{tabular}{|c|c|c|c|c|}
\hline \multicolumn{3}{|c|}{ Construct } & AVE & CR \\
\hline \multicolumn{3}{|c|}{ CSR economic dimension } & 0.502 & 0.75 \\
\hline \multicolumn{3}{|c|}{ CSR Legal dimension } & 0.572 & 0.841 \\
\hline \multicolumn{3}{|c|}{ CSR Ethical dimension } & 0.509 & 0.837 \\
\hline \multicolumn{3}{|c|}{ CSR Philanthropic } & 0.601 & 0.899 \\
\hline \multicolumn{3}{|c|}{ Service Quality } & 0.513 & 0.894 \\
\hline \multicolumn{3}{|c|}{ Purchase Intentions } & 0.618 & 0.906 \\
\hline \multirow[b]{2}{*}{ Hypothesis } & \multicolumn{2}{|c|}{ Path coefficients } & \multirow[b]{2}{*}{$\begin{array}{c}\text { Values } \\
\beta_{\text {(t-value })^{\text {Sig. }}}\end{array}$} & \multirow[b]{2}{*}{ Decision } \\
\hline & $\begin{array}{c}\text { Exogenous } \\
\text { Variable }\end{array}$ & $\begin{array}{c}\text { Endogenous } \\
\text { Variable }\end{array}$ & & \\
\hline $\mathbf{H}_{1}$ & $\begin{array}{l}\text { CSR economic } \\
\text { dimension }\end{array}$ & $\begin{array}{l}\text { Purchase } \\
\text { intentions }\end{array}$ & $0.100_{(1.704)} 0.088$ & Rejected \\
\hline $\mathbf{H}_{2}$ & CSR legal dimension & $\begin{array}{l}\text { Purchase } \\
\text { intentions }\end{array}$ & $0.042_{(0.700)} 0.484$ & Rejected \\
\hline $\mathbf{H}_{3}$ & CSR ethical dimension & $\begin{array}{l}\text { Purchase } \\
\text { intentions }\end{array}$ & $0.209_{(3.150)^{0.002}}$ & Supported ${ }^{* * *}$ \\
\hline $\mathbf{H}_{4}$ & $\begin{array}{l}\text { CSR philanthropic } \\
\text { dimension }\end{array}$ & $\begin{array}{l}\text { Purchase } \\
\text { intentions }\end{array}$ & $0.110_{(2.108)}{ }^{0.035}$ & Supported ${ }^{* * *}$ \\
\hline $\mathbf{H}_{5}$ & $\begin{array}{l}\text { CSR economic } \\
\text { dimension }\end{array}$ & Service quality & $0.064_{(1.231)} 0.219$ & Rejected \\
\hline $\mathrm{H}_{6}$ & CSR legal dimension & Service quality & $0.064_{(1.132)}{ }^{0.258}$ & Rejected \\
\hline $\mathbf{H}_{7}$ & CSR ethical dimension & Service quality & $0.391_{(7.337)} 0.000$ & Supported ${ }^{* * *}$ \\
\hline $\mathbf{H}_{8}$ & $\begin{array}{l}\text { CSR philanthropic } \\
\text { dimension }\end{array}$ & Service quality & $0.101_{(1.945)}{ }^{0.052}$ & Rejected \\
\hline $\mathbf{H}_{9}$ & Service quality & $\begin{array}{l}\text { Purchase } \\
\text { intentions }\end{array}$ & $\left.0.259_{(4.108)}\right)^{0.000}$ & Supported $^{* * *}$ \\
\hline
\end{tabular}

As shown in Table 2 , at a 95\% confidence level, $\mathrm{t}$-value \pm 1.96 , and $\mathrm{p}$ value $<$ $0.05 \mathrm{H}_{1}, \mathrm{H}_{2}, \mathrm{H}_{5}, \mathrm{H}_{6}$ and $\mathrm{H}_{8}$ were not accepted. Thus, $\mathrm{H}_{3}, \mathrm{H}_{4}, \mathrm{H}_{7}$ and $\mathrm{H}_{9}$ were all supported. To test the indirect association between the constructs, the approach suggested by Preacher and Hayes $(2004 ; 2008)$ and Hayes (2013) was followed, as illustrated in Table 3.

First, the direct relationships between CSR dimensions and Purchase were examined (step 1). To proceed with the analysis of the mediators' effects, the direct relationship needs to be significant (Hair et al., 2014) (see Table 3).

Second, to measure the indirect effects of service quality, the mediator was introduced, and that relationship was examined again (step 2). Third, the total impact of the exogenous variable on the endogenous variable was calculated (Step 3). Finally, the variance accounted for (VAF) (mediation effects) was computed and the hypothesis involving service quality was accordingly assessed in light of the values of the VAF. 
More specifically, if the VAF of the proposed mediator is less than 0.2, then the variable does not have a mediating effect; if the VAF ranges from 0.2 to 0.8 , then the variable has a partial mediating effect and if the VAF is over 0.8 , then the variable has a full mediating effect (Preacher \& Hayes, 2004; 2008).

Table 3

Results of Examining the Mediation Impacts

\begin{tabular}{|c|c|c|c|c|}
\hline \multirow{5}{*}{$\stackrel{\text { के }}{=}$} & \multicolumn{2}{|c|}{ Direct Path coefficients without mediator } & $\beta$ & Decision \\
\hline & \multirow{4}{*}{\multicolumn{2}{|c|}{$\begin{array}{l}\text { CSR Economic dimension } \rightarrow \text { Purchase } \\
\text { Intentions } \\
\text { CSR Legal dimension } \rightarrow \text { Purchase Intentions } \\
\text { CSR Ethical dimension } \rightarrow \text { Purchase Intentions } \\
\text { CSR Philanthropic dimension } \rightarrow \text { Purchase } \\
\text { Intentions }\end{array}$}} & $0.136_{(2.599)}^{0.009 * *}$ & Go to step (2) \\
\hline & & & $0.052_{(0.855)^{0.393}}$ & No mediation \\
\hline & & & $0.310_{(5.331)^{0.000 * * *}}$ & Go to step (2) \\
\hline & & & $0.135_{(2.669)^{0.008^{* *}}}$ & Go to step (2) \\
\hline \multirow{4}{*}{ हैं त्ञ } & \multicolumn{4}{|c|}{$\begin{array}{l}\text { Indirect Path coefficients } \\
\text { with the mediator= (independent to mediator. mediator to dependent) (see Table 1) }\end{array}$} \\
\hline & \multirow{3}{*}{\multicolumn{2}{|c|}{$\begin{array}{l}\text { CSR Economic dimension } \rightarrow \text { Purchase } \\
\text { Intentions } \\
\text { CSR Ethical dimension } \rightarrow \text { Purchase Intentions } \\
\text { CSR Philanthropic dimension } \rightarrow \text { Purchase } \\
\text { Intentions }\end{array}$}} & $0.017_{(1.154)^{0.249}}$ & No mediation \\
\hline & & & $0.101_{(3.568)^{0.000 * * *}}$ & Go to step (3) \\
\hline & & & $0.026_{(1.677)^{0.094}}$ & No mediation \\
\hline \multirow{2}{*}{ के } & \multicolumn{4}{|c|}{$\begin{array}{l}\text { Total Path coefficients } \\
\text { with the mediator= (Direct }+ \text { Indirect effect })\end{array}$} \\
\hline & \multirow{2}{*}{\multicolumn{4}{|c|}{$\begin{array}{l}\text { CSR Ethical dimension } \rightarrow \text { Purchase Intentions } \quad 0.310_{(5.230)}^{0.000^{* * *}} \text { Go to st } \\
\text { Mediation effect Vairance Accounted For VAF }=(\text { Indirect effect/Total effect })\end{array}$}} \\
\hline \multirow{3}{*}{ क्षे } & & & & \\
\hline & $\begin{array}{l}\text { Independent } \\
\text { Variable }\end{array}$ & $\begin{array}{l}\text { Dependent } \\
\text { Variable }\end{array}$ & VAF & Decision \\
\hline & $\begin{array}{l}\text { CSR Ethical } \\
\text { dimension }\end{array}$ & $\begin{array}{l}\text { Purchase } \\
\text { Intentions }\end{array}$ & 0.326 & $\begin{array}{c}\text { Partial } \\
\text { supported }\end{array}$ \\
\hline
\end{tabular}

According to the results shown in Table $3, \mathrm{H}_{12}$ was partially supported, where service quality was found to partially mediate the relationship between CSR ethical dimension and purchase intentions.

\section{CONCLUSION, RECOMMENDATION, LIMITATION AND FUTURE RESEARCH}

\subsection{Conclusion and Recommendation}

As the concept of corporate social responsibility is relatively new in Egypt, many people have uncertain feelings of what socially responsible means. In addition, misunderstanding of the concept corporate social responsibility might have led to wrong perceptions. So that, this study includes four dimensions of corporate social responsibility (economic responsibility, moral responsibility, legal responsibility, and philanthropic responsibility) and their impact on purchase intention in the presence of the service quality as a mediator variable. Results concluded that there is a direct impact of both the economic and Ethical responsibility and philanthropic on purchase intention, there is also a direct effect of Ethical responsibility and philanthropic on service quality.

Results also showed that there is a direct effect of the service quality on the purchase intention, through the previous results of the study show that does not have a sufficient perception of legal responsibility, therefore organizations should pay attention to such a dimension because of its importance in organizations enhance 
customer confidence and give a clear picture and sound legal procedures to be carried out, finally, the need for companies to fully disclose information on social activities carried out during the year, and the consequent social costs to be registered and classified clearly and thoroughly, like the economic costs expended by the company on its various activities and in the books and records of the company, and then presented in the reports and financial statements published in the media, until members of society assess the social role of the company.

\subsection{Limitations and Future Research}

1) The need to study the practices of corporate social responsibility on industrial scale, where this study was confined to the service sector only.

2) Should study the response of all stakeholders toward socially responsible companies and not just as consumers; adopted a definition of marketing now hand stakeholders' trend instead of a narrow approach to customers.

3) It should be in future sample include lower levels of Educational \& income in order to obtain a more comprehensive view of the customer response in the Egyptian environment.

4) Need study the impact of the legal dimension of corporate social responsibility on purchase intentions.

5) Study the impact of CSR on the financial performance.

6) Explore the impact of demographic factors on corporate social responsibility.

\section{REFERENCES}

Abdullah, T. M. K., \& Budiman, P. (2019, January 26-28). The Role of Corporate Social Responsibility Towards Purchase Intention: The Mediating Effect of Brand Image and Corporate Reputation. Paper presented at the $1^{\text {st }}$ Workshop on Multimedia Education, Learning, Assessment and its Implementation in Game and Gamification, Medan, Indonesia, Womela-GG. Doi: 10.4108/eai.26-12019.2283201.

Ackerman, R. W. (1973, January). How companies respond to social demands. Harvard Business Review, 51(4), 88-98.

Argo, J. J., \& Main, K. J. (2004). Meta-analyses of the effectiveness of warning labels. Journal of Public Policy \& Marketing, 23(2), 193-208.

Arikan, E., \& Güner, S. (2013, November). The impact of corporate social responsibility, service quality and customer-company identification on customers. Procedia-Social \& Behavioral Sciences, 99, 304-313.

Baughn, C. C., Bodie, N. L., \& McIntosh, J. C. (2007). Corporate social and environmental responsibility in Asian countries and other geographical regions. Corporate Social Responsibility \& Environmental Management, 14(4), 189-205.

Carroll, A. B. (1979, October). A three-dimensional conceptual model of corporate performance. The Academy of Management Review, 4(4), 497-505.

Carroll, A. B. (1991, July). The pyramid of corporate social responsibility: Toward the moral management of organizational stakeholders. Business Horizons, 34(4), 39-48.

Carroll, A. B. (2016, December). Carroll's pyramid of CSR: Taking another look. International Journal of Corporate Social Responsibility, 1(1), 1-8.

Carroll, A. B., \& Buchholtz, A. K. (2002, February). Business and society with infotrac: Ethics and stakeholder management (5 $5^{\text {th }}$ ed.). Cincinnati, USA: South-Western College Pub.

Cassel, D. (2001, April). Human rights and business responsibilities in the global marketplace. Business Ethics Quarterly, 11(2), 261-274. 
Chandler, D. (2019, July). Strategic corporate social responsibility: Sustainable value creation (5 $5^{\text {th }}$ ed.). Thousand Oaks, CA, USA: SAGE Publications, Incorporated.

Chen, C. C., Lin, S. Y., Cheng, C. H., \& Tsai, C. C. (2012, June). Service quality and corporate social responsibility, influence on post-purchase intentions of sheltered employment institutions. Research in Developmental Disabilities, 33(6), 1832-1840.

Choudhury, K. (2013). Service quality and WOM (word-of-mouth): A study of the Indian banking sector. International Journal of Customer Relationship Marketing \& Management, 2(2), 63-87.

Collis, J., \& Hussey, R. (2009). Business research (3 ${ }^{\text {rd }}$ ed.). Basingstoke, Hampshire, UK: Palgrave Macmillan.

Cornwell, T. B., \& Coote, L. V. (2005, February). Corporate sponsorship of a cause: The role of identification in purchase intent. Journal of Business Research, 58(3), 268-276.

Davis, K. (1960, April). Can business afford to ignore social responsibilities? California Management Review, 2(3), 70-76.

Deng, J., \& Qian, M.Y. (2011). Counselors' implicit ethical attitude towards dual relationship. Chinese Mental Health Journal, 25(12), 897-903.

Dentchev, N. A. (2009). To what extent is business and society literature idealistic? Business \& Society, 48(1), 10-38.

Fatma, M., Khan, I., \& Rahman, Z. (2016, August). The effect of CSR on consumer behavioral responses after service failure and recovery. European Business Review, 28(5), 583-599.

Foo, D. S. T., \& Yazdanifard, R. (2014). Does corporate social responsibility make any differences when it comes to "un-substitutable" product from customer point of view. Journal of Research in Marketing, 2(2), 167-171.

Foster, M. K., Meinhard, A.G., Berger, I. E., \& Krpan, P. (2009, June). Corporate philanthropy in the Canadian context: From damage control to improving society. Nonprofit \& Voluntary Sector Quarterly, 38(3), 441-466.

Garriga, E., \& Melé, D. (2004). Corporate social responsibility theories: Mapping the territory. Journal of Business Ethics, 53(1), 51-71.

Gigauri, I. (2012, November). Impact of corporate social responsibility on consumer purchase decision. Journal of Educational \& Social Research, 2(9), 106-106.

González-Rodríguez, M. R., \& Díaz-Fernández, M. C. (2020, February). Customers' corporate social responsibility awareness as antecedent of repeat behaviour intention. Corporate Social Responsibility \& Environmental Management, 27(3), 12941306.

Gopal, A., \& Srinivasan, R. (2006, October). The new Indian consumer. Harvard Business Review, 84(10), 22-23.

Gottlieb, U. R., Brown, M. R., \& Drennan, J. (2011, November). The influence of service quality and trade show effectiveness on post-show purchase intention. European Journal of Marketing, 45(11/12), 1642-1659.

Hair, J., Hult, G., Ringle, C., \& Sarstedt, M. (2014). A primer on partial least squares structural equation modelling (PLS-SEM). Los Angeles: Sage Publications.

Hair, J., Sarstedt, M., Ringle, C., \& Mena, J. (2012). An assessment of the use of partial least squares structural equation modelling in marketing research. Journal of the Academy of Marketing Science, 40(3), 414-433.

Hassan, H., Hashmi, M. S., \& Sarwar, Z. (2014). Exploring the impact of retail stores' service quality on consumers' purchase intention: The moderating role of CSR. Middle-East Journal of Scientific Research, 19(4), 505-520. 
Hayes, A. (2013). Introduction to Mediation, moderation and conditional process analysis: A regression-based approach. New York: The Guilford Press.

He, H., \& Li, Y. (2011). CSR and service brand: The mediating effect of brand identification and moderating effect of service quality. Journal of Business Ethics, 100(4), 673-688.

Henderson, J. C. (2007). Corporate social responsibility and tourism: Hotel companies in Phuket, Thailand, after the Indian ocean tsunami. International Journal of Hospitality Management, 26(1), 228-239

Henseler, J., Ringle, C., \& Sinkovics, R. (2009). The use of partial least squares path modelling in international marketing. Advances in International Marketing, 20, 277320.

Hsu, K. T. (2012). The advertising effects of corporate social responsibility on corporate reputation and brand equity: Evidence from the life insurance industry in Taiwan. Journal of Business Ethics, 109(2), 189-201.

Huang, C. -C., Yen, S. -W., Liu, C. -Y., \& Huang, P. -C. (2014). The relationship among corporate social responsibility, service quality, corporate image and purchase intention. International Journal of Organizational Innovation (Online), 6(3), 68-84.

Huang, J. -L., Yeh, L. -Y., \& Chien, H. -Y. (2011, January). ABAKA: An anonymous batch authenticated and key agreement scheme for value-added services in vehicular ad hoc networks. IEEE Transactions on Vehicular Technology, 60(1), 248262.

Husted, B. W., \& Allen, D. B. (2000). Is it ethical to use ethics as strategy? Journal of Business Ethics, 27(1/2), 21-31.

Jensen, M., \& Meckling, W. (1976). Theory of the firm: Managerial behavior, agency cost, and capital structure. Journal of Financial Economics, 3(4), 305-360.

Kolkailah, S. K., Aish, E. A., \& El-Bassiouny, N. (2012, July). The impact of corporate social responsibility initiatives on consumers' behavioral intentions in the Egyptian market. International Journal of Consumer Studies, 36(4), 369-384

Kotler, P., \& Lee, N. (2005), Corporate social responsibility: Doing the most good for your company and your cause. Hoboken, NJ: John Wiley \& Sons.

Krejcie, R. V., \& Morgan, D. W. (1970). Determining sample size for research activities. Educational \& Psychological Measurement, 30, 607-610.

Kuo, Y. F., Wu, C. M., \& Deng, W. J. (2009). The relationships among service quality, perceived value, customer satisfaction, and post-purchase intention in mobile value-added services. Computers in Human Bebavior, 25(4), 887-896.

Lacey, R., Kennett-Hensel, P. A., \& Manolis, C. (2015). Is corporate social responsibility a motivator or hygiene factor? Insights into its bivalent nature. Journal of the Academy of Marketing Science, 43(3), 315-332.

Lantos, G.P., (2001). The boundaries of strategic corporate social responsibility. Joumal of Consumer Marketing, 18(7), 595-632.

Lee, H., Park, T., Moon, H. K., Yang, Y., \& Kim, C. (2009). Corporate philanthropy, attitude towards corporations, and purchase intentions: South Korea study. Journal of Business Research, 62(10), 939-946.

Lichtenstein, D. R., Drumwright, M. E., \& Braig, B. M. (2004). The effect of corporate social responsibility on customer donations to corporate-supported nonprofits. Journal of Marketing, 68(4), 16-32.

Ling, K. C., Chai, L. T., \& Piew, T. H. (2010, July). The effects of shopping orientations, online trust and prior online purchase experience toward customers' online purchase intention. International Business Research, 3(3), 63-76. 
Maignan, I., \& Ferrell, O. C., (2003). Nature of corporate responsibilities: Perspectives from American, French, and German consumers. Journal of Business research, 56(1), $55-67$.

Malhotra, N. \& Birks, D. (2007). Marketing research: An applied approach (3 ${ }^{\text {rd }}$ ed.). Harlow, UK: Pearson Education.

Malhotra, N. K. (2011). Review of marketing researcb: Special issue-marketing legends (vol. 8). Bingley, UK: Emerald Group Publishing Limited.

Martínez, J. B., Fernández, M. L., \& Fernández, P. M. R. (2016). Corporate social responsibility: Evolution through institutional and stakeholder perspectives. European Journal of Management \& Business Economics, 25(1), 8-14.

Matten, D., \& Crane, A. (2005). Corporate citizenship: Toward an extended theoretical conceptualization. Academy of Management Review, 30(1), 166-179.

Menichini, T., \& Rosati, F. (2014, January). The strategic impact of CSR consumercompany alignment. Procedia-Social \& Behavioral Sciences, 109, 360-364

Mohr, L. A., \& Webb, D. J. (2005). The effects of corporate social responsibility and price on consumer responses. Journal of Consumer Affairs, 39(1), 121-147.

Murray, K. B., \& Montanari, J. B. (1986). Strategic management of the socially responsible firm: Integrating management and marketing theory. Academy of Management Review, 11(4), 815-827.

Parasuraman, A., Berry, L. L., \& Zeithaml, V. A. (1993). More on improving service quality measurement. Journal of Retailing, 69(1), 140-147.

Park, J., Lee, H., \& Kim, C. (2014). Corporate social responsibilities, consumer trust and corporate reputation: South Korean consumers' perspectives. Journal of Business Research, 67(3), 295-302.

Parsons, T. (1961). An outline of the social system. In Classical Sociological Theory (2 ${ }^{\text {nd }}$ ed., pp. 421-440). Malden MA, USA: Wiley-Blackwell Publ.

Payton, R. L. (1988). Philanthropy: Voluntary action for the public good. New York: American Council on Education.

Pérez, M. S., Abad, J. C. G., Carrillo, G. M. M., \& Fernández, R. S. (2007, March). Effects of service quality dimensions on behavioural purchase intentions: A study in public-sector transport. Managing Service Quality: An International Journal. 17(2), 134-151.

Potočan, V., \& Mulej, M. (2009, January). How to improve innovativeness of small and medium enterprises. Management: Journal of Contemporary Management Issues, 14(1), 120.

Preacher, K., \& Hayes, A. (2004). SPSS and SAS procedures for estimating indirect effects in simple mediation models. Behaviour Research Methods, Instruments, \& Computers, 36(4), 717-731.

Preacher, K., \& Hayes, A. (2008). Asymptotic and re-sampling strategies for assessing and comparing indirect effects in multiple mediator models. Behaviour Research Methods, 40(3), 879-891.

Preston, L. E., \& Post, J. E. (1981, April). Private management and public policy. California Management Review, 23(3), 56-62.

Rexhepi, G., Kurtishi, S., \& Bexheti, G. (2013, April). Corporate social responsibility (CSR) and innovation-the drivers of business growth? Procedia-Social \& Behavioral Sciences, 75, 532-541.

Ringle, C. M., Wende, S., \& Becker, J. -M. (2015, January). Smart PLS 3. Bönningstedt: Smart PLS GmbH, http://www.smartpls.com. 
Sen, S., Bhattacharya, C. B., \& Korschun, D. (2006, March). The role of corporate social responsibility in strengthening multiple stakeholder relationships: A field experiment. Journal of the Academy of Marketing Science, 34(2), 158-166.

Servaes, H., \& Tamayo, A. (2013). The impact of corporate social responsibility on firm value: The role of customer awareness. Management Science, 59(5), 1045-1061.

Smith, W., \& Higgins, M. (2000). Cause-related marketing: Ethics and the ecstatic. Business \& Society, 39(3), 304-322.

Staiculescu, O. (2014, January). Quality and social responsibility: A pathway to the future. Procedia-Social \& Behavioral Sciences, 109, 241-245.

Sturdivant, F. D. (1979, Fall). Executives and activists: Test of stakeholder theory. California Management Revien (pre-1986), 22(1), 53-59.

Sureshchandar, G. S., Rajendran, C., \& Anantharaman, R. N. (2002, July). The relationship between service quality and customer satisfaction-a factor specific approach. Journal of Services Marketing, 16(4), 363-379.

Torres, I. M., Sierra, J. J., \& Heiser, R. S.(2007). The effects of warning-label placement in print ads: A social contract perspective. Journal of Advertising, 36(2), 49-62.

Vaijayanthi, P., Shreenivasan, K. A., \& Roy, R. (2012, August 17-18). Antecedents to customer purchase intention - an empirical study of sservice quality and customer satisfaction in food services in the Indian milien (pp. 20-24). International Conference on Management Issues in Emerging Economies (ICMIEE), Thanjavur, Tamilnadu, India.

Valand, T. I., Heide, M., \& Grønhaug, K. (2008, September). Corporate social responsibility: Investigating theory and research in the marketing context. European Journal of Marketing, 42(9/10), 927-953.

Varadarajan, P. R., \& Menon, A. (1988, July). Cause-related marketing: A coalignment of marketing strategy and corporate philanthropy. The Journal of Marketing, 52(3), 58-74.

Vlachos, P. A., Tsamakos, A., Vrechopoulos, A. P., \& Avraamides, P. K. (2009, June). Corporate social responsibility: Attributions, loyalty, and the mediating role of trust. Journal of the Academy of Marketing Science, 37(2), 170-180.

Walker, H., \& Brammer, S. (2009). Sustainable procurement in the United Kingdom public sector. Supply Chain Management, 14(2), 128-137.

Walsh, G., \& Bartikowski, B. (2013). Exploring corporate ability and social responsibility associations as antecedents of customer satisfaction crossculturally. Journal of Business Research, 66(8), 989-995.

Wang, A. (2009, June). Perceptions of corporate social responsibility practices on mobile phone companies. International Journal of Mobile Marketing, 4(1), 62-68.

Wattanakamolchai, S., Signal, M., \& Murrmann, S. K. (2014, March). Socially responsible customers and the evaluation of service quality. Journal of Hospitality \& Tourism Research, 40(6), 715-738.

Welford, R. J. (2004, March). Corporate social responsibility in Europe and Asia: Critical elements and best practice. Journal of Corporate Citizenship, 13, 31-47.

Wood, D. J. (1991, June). Social issues in management: Theory and research in corporate social performance. Journal of Management, 17(2), 383-406

$\mathrm{Xu}, \mathrm{Y}$. (2014, April). CSR impact on hospital duopoly with price and quality competition. Journal of Applied Mathematics, 1-12. Doi: 10.1155/2014/152060.

Zeithaml, V. A., Berry, L. L., \& Parasuraman, A. P. (1996, April). The behavioral consequences of service quality. The Journal of Marketing, 60(2), 31-46. 


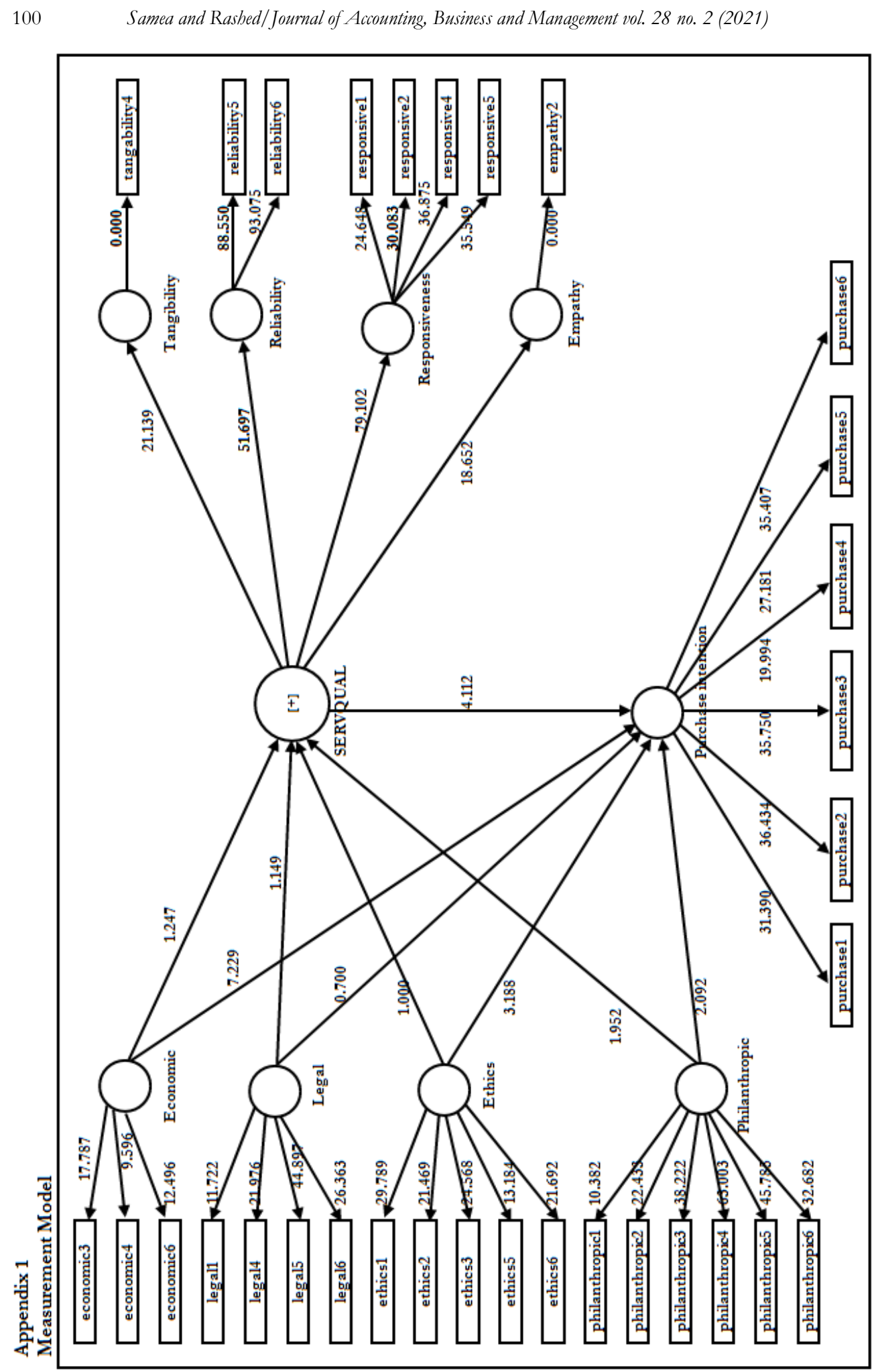




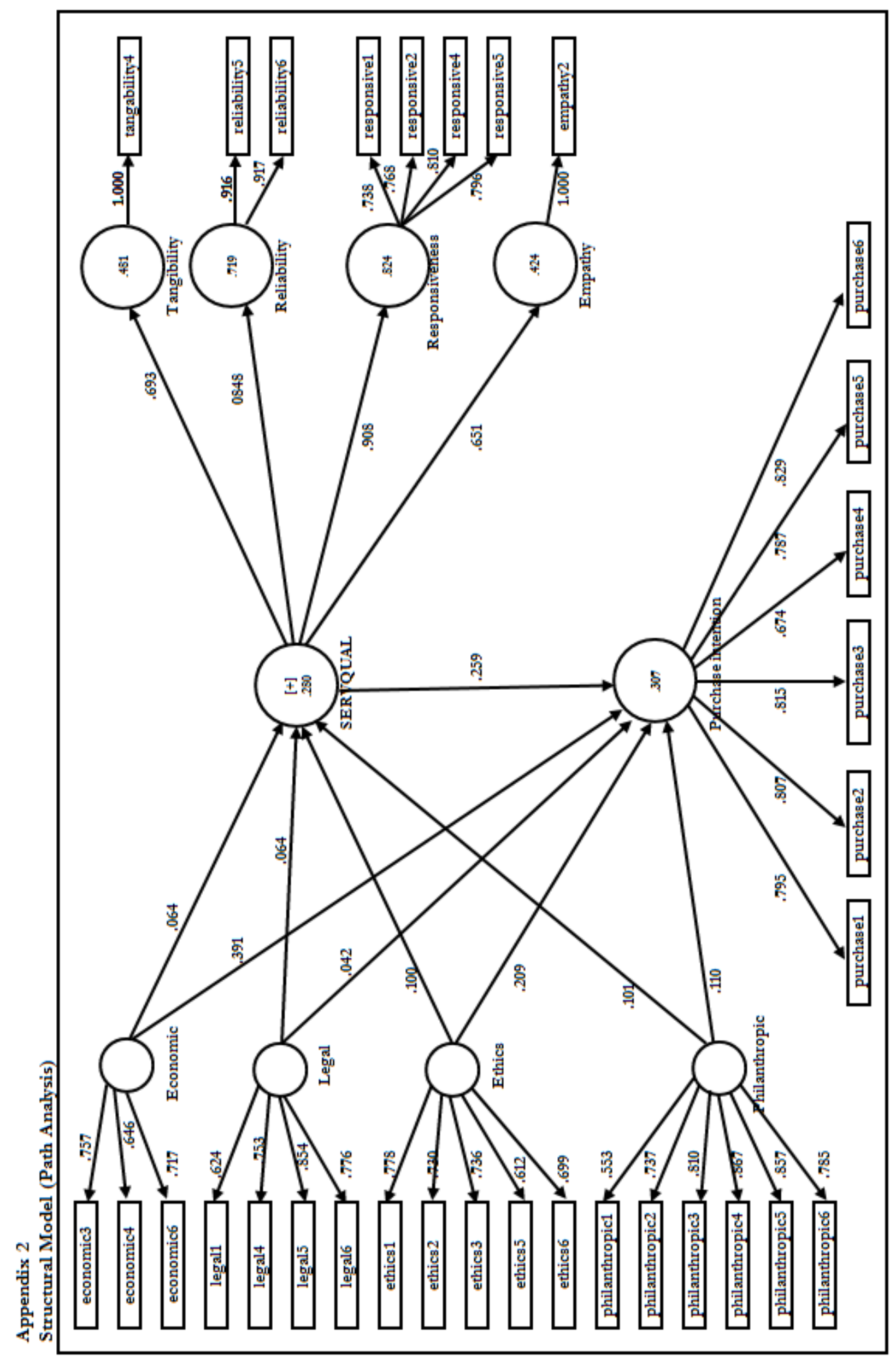


Appendix 3

Questionnaire Items

1. Corporate Social Responsibility

1.1. Economic Responsibility

1.1.1. The company's first goal is to attract the customers to engage a profit through the practice of community activities such as (literacy, renewing schools ... etc.)

1.1.2. The company seeks to reduce the costs such as (taxes, rents, advertising ... etc.) through the practices of social responsibility.

1.1.3. The company has become more interested in society than just making profits.

1.1.4. The company is always trying to improve economic performance.

1.1.5. The company is trying to maximize long-term success.

1.1.6. The company contributes a portion of its profits to the community.

\subsection{Legal responsibility}

1.2.1. The company seeks to comply with all laws and government regulations through the publication of annual financial reports in official newspapers.

1.2.2. You get bills and contracts when you buy lines of mobile from the company.

1.2.3. The Company ensures that its employees do not receive commissions, gratuities... etc., from you.

1.2.4. The company complies with all rules and regulations of the State although it is costly for them such as (insurance of its employees, etc.).

1.2.5. The company respects the law when carrying out its activities.

1.2.6. The company is keen to avoid fraud and tax fraud.

\subsection{Ethical responsibility}

1.3.1. The company acts honestly and sincerely with its customers.

1.3.2. The company has participated in this activity because it feels it is ethically committed to helping the community

1.3.3. The company respects ethical principles before achieving a distinct economic performance.

1.3.4. You feel that you have a moral duty to buy a service from responsible services.

1.3.5. To be sure to ensure the honesty and integrity of the company and its employees so that your choice more credible.

1.3.6. The keenness of those working in it not to carry out abusive practices

\subsection{Philanthropic responsibility}

1.4.1. The company will cover some social issues such as charity donations (by sending free messages from your mobile).

1.4.2. The company strives to improve society (water delivery to disadvantaged areas, etc.).

1.4.3. The company works to activate and promote volunteer work (participation in literacy campaigns, etc.).

1.4.4. The company is engaged in social responsibility activities to combat poverty.

1.4.5. The company draws part of its budget for donations to poor groups.

1.4.6. The company feels its commitment to improving the welfare of the community.

\section{Service quality}

2.1 Tangibility

2.1.1. The company has highly professional staff.

2.1.2. The company owns facilities and halls convenient, attractive and comfortable to work (air conditioning, comfortable seats .... etc.).

2.1.3. The staff at the company have an elegant counterpart.

2.1.4. The service we receive is in accordance with the required specifications.

2.1.5. The presence of equipment and sophisticated equipment.

2.1.6. Facilities and parking are convenient and attractive. 
To be continued form Appendix 3

\subsection{Reliability}

2.2.1. Commitment to implement and provide services at specified times (the waiting period in the company reflects the quality of service.

2.2.2. Attention to the problems of customers by answering your questions and speed resolved.

2.2.3. Sound quality is good.

2.2.4. The company provides modern electronic systems to register customers to facilitate contact with them.

2.2.5. The company is keen to provide the service correctly from the first time.

2.2.6. You think this company usually offers a high-quality service.

\subsection{Responsiveness}

2.3.1 The company responds to customer requests (such as new suggestions).

2.3.2 The company is ready to solve problems quickly.

2.3.3 The company offers special services (such as free minutes, prizes)

2.3.4 The service provider understands the importance of time for me.

2.3.5 Inform the client of the exact dates of service delivery.

2.3.6 The waiting period is short to provide service to the customer.

\subsection{Assurance}

2.4.1. Staff behavior makes you feel confident in the company.

2.4.2. You feel secure in dealing with the company such as (call secret).

2.4.3. Confident that the staff will not offend uses personal information.

2.4.4. Employees have sufficient knowledge to answer customer questions.

2.4.5. Employees treat customers with respect.

2.4.6. Permanent readiness to help customers.

\subsection{Empathy}

2.5.1. The company is interested in knowing the needs of customers through the (complaint box, hear your complaint by officials when viewed in the phone).

2.5.2. The company put the supreme interest of the clients of the priorities of management and employees of the company.

2.5.3. Officials at the customer service to respond to inquiries in a manner characterized by the skill and speed of performance.

2.5.4. The company offers convenient services for various clients (new bouquets, reduce call rate, etc.).

2.5.5. Professional staff handling problems.

2.5.6. Good treatment and respect for customers.

\subsection{Purchase intention}

2.6.1. Services of this company can be your first choice.

2.6.2. You have the intention and willingness to purchase new services provided by this company when you view them.

2.6.3. Purchase of services offered by this company is a good idea.

2.6.4. You can pay a higher price for the services of this company.

2.6.5. When a friend is looking for a service of this kind, you advise him to purchase this service from this company.

2.6.6. Purchase of services for this service is a wise choice. 